Article

\title{
Employee Commitment Matters for CSR Practice, Reputation and Corporate Brand Performance-European Model
}

\author{
Wioleta Kucharska \\ Management Department, Faculty of Management and Economics, Gdansk University of Technology, \\ 80-233 Gdańsk, Poland; wioleta.kucharska@pg.edu.pl
}

Received: 26 December 2019; Accepted: 19 January 2020; Published: 27 January 2020

\begin{abstract}
So far, there have been no studies that explore how employee brand commitment moderates CSR practice outcomes. Employee brand commitment is often claimed as a focal input and output of the CSR. So, it means that it shapes CSR conditions. Then, it is a moderator. This study aims to verify it. Besides, commitment exists in many forms and can be achieved in many ways. Hence the question, if employees are committed to the brand, then how does it affect the outcomes of social responsibility practices such as corporate reputation or brand performance? This study analyzed a sample of 282 cases from the construction industry in Europe, using SPSS Amos and the PROCESS macro, to reveal the strong alignment of an excellent level of all three: CSR practice, corporate brand reputation, employee brand commitment. Still, it also shows that the high level of CSR practice may leverage corporate brand reputation even though employees are not brand committed. It exposes how meaningful the excellent level of CSR practice is. Moreover, the study also reveals that the lack of employee brand commitment may jeopardize reputation. So, the simplest way to achieve sustainability of brand performance is to keep employee brand commitment and CSR practice at the highest possible level to secure corporate brand reputation, which is a strong mediator between CSR practice and brand performance. The people are the company. So, in light of the study findings, it is clear that the future of corporate brands is in employees' hands. Thus, companies should focus on improving employee commitment to achieve better corporate social responsibility practice outcomes. Moreover, the findings in this study present evidence supporting the importance of internal branding. This is the first study that has explored how employee brand commitment moderates CSR outcomes in a national context.
\end{abstract}

Keywords: CSR practice; corporate brand reputation; brand performance; employee brand commitment; internal branding

\section{Introduction}

Brands are one of the key intangible assets of a company. They significantly influence the company's competitive advantage and income [1]. Moreover, strong brands are powerful and can leverage countries' economies [2]. Brands are a key asset created by employees, who have the power to create a competitive advantage for their company. Corporate responsibility and the strength of the company's brand are some of the top drivers of employee engagement [3]. Thus, employee brand commitment (EBC), corporate social responsibility (CSR), corporate brand reputation (CR), and company performance (BP) are not only significant factors in a company's success but they are also closely related and support each other. Hence, in the context of a circular economy, the mechanism of their relationships, which changes the way companies conduct business, is worth exploring in more depth [4]. 
CSR reporting has resulted in companies facing increasing demands to be socially responsible. According to stakeholder theory [5], employee involvement is pivotal in the successful implementation of CSR practice (CSRp) [6] because the daily efforts and routines of employees shape the company's performance. Testa, Boiral, and Iraldo [7] stressed that CSR performance depends on employee commitment. Hamadamin and Atan [8] described a sustainable competitive advantage as an employee's commitment output. Hence, this study aims to provide up-to-date knowledge about the structure and influence of employee commitment, CSR, corporate brand reputation, and brand performance.

Employee commitment has recently received quite a lot of attention from human resources (HR) managers and scientists [9,10]. Dixon-Fowler et al. [11] proposed a sustainable HR model that included commitment as a significant predictor of employee loyalty and the performance of an organization. Engagement reflects the enthusiasm in acting (e.g., towards work); commitment reflects the bond with the organization as a place of work [12]. Both constructs are closely related and may be perceived to be proxies for one another. However, it is possible for an employee to be committed to the organization but not engaged in their job, and vice versa. According to Becker [13,14], commitment is a consistent favorable behavior towards the object to which the commitment is observed. Thus, corporate brand commitment is consistent positive behavior towards the corporate brand and is a core driver of brand-aligned behaviors [15]. Consistent employee commitment behavior increases corporate brand value [16] and may significantly moderate all corporate brand relationships. Given that employees are the main supporters of CSR strategies [7], does employee brand commitment moderate relationships with CSRp, reputation, and corporate brand performance? If so, how are they shaped? This study aims to answer.

Some studies have shown that employee brand commitment is driven by a company's brand reputation [17,18]. In contrast, Wæraas and Dahle [19] claimed that employees are reputation ambassadors. Moreover, committed employees are efficient brand builders, according to de Chernatony et al. [20], who create a company's real value [21]. Gupta [22] claimed that CSR influences employee workplace behavior. Kowalczyk and Kucharska [23,24] inspired by Cheung et al. [25] and Garas et al. [26] noted that employee's commitment, next to brand reputation is one of the key CSRp outcomes. So, there is a high level of probability that employee brand commitment is a focal input and output of the CSRp. It means that EBC shapes conditions for CSR practices. So, it is a focal moderator, probably. This study aims to verify it. Thus, it is worth exploring how employee brand commitment moderates the relationships between CSRp, reputation, and corporate brand performance. The construction industry in Europe, which is the most invasive and faces the strictest laws to ensure safety, constitutes a good case study to analyze the above aims. Table 1 summarizes the framework presented in this study. 
Table 1. Study framework.

The theoretical model was verified on 282 cases collected electronically across Europe-mainly via emails addressed to human resources departments in construction companies from April to June 2019.

Method of data analysis:

a. SEM model (SPSS AMOS 25 software); H1: H3 verification.

b. Regression model (PROCESS macro software); moderated mediation and moderated moderation verifications; $\mathrm{H} 4$ : $\mathrm{H} 5$ verification.

This is the first study that has explored employee brand commitment as a moderator of
CSR practice outcomes such as corporate brand reputation and brand performance in a
national context.

\section{Literature Review and Hypotheses Formulation}

Value creation is a central concept in management studies [27]. A company's brand is a source of its value [28], and committed employees make a significant contribution to the value creation of the company's brand [29]. Companies' ethical values enhance brand commitment [30,31]. Employee brand commitment is a psychological process involved in "brand citizenship behavior" and is defined as a strong bond between the employer's brand and the employee [31].

Employees' CSR engagement is vital to the success of CSR [32-36]. McShane and Cunningham [37] called employees internal CSR "ambassadors." Most CSR studies, including those on employees' perceptions, have focused on the effect of CSR on employees' identification or engagement as a focal group of stakeholders.

Glavas [38-40], Caligiuri [41], and Gupta [22] proved that employees' positive perceptions of CSR enhance organizational commitment. Many positive employee outcomes have resulted from CSRp [42], including commitment [43-46] and employee identification with the company's brand [47-49].

According to Thompson and Bunderson [50], an ideology-infused psychological contract (IPC) based on common values leads to employee commitment that benefits both the organization and the employee. Thus, CSR can be considered a 'common ideology.'

Few studies have examined how employee brand commitment affects CSR outcomes. Commitment exists in many forms and can be achieved in many ways [51,52]. As employee commitment is an evident source of value, it becomes an increasingly important topic for researchers. According to Dixon-Fowler et al. [10], present-day workers are more engaged in their jobs but not as committed 
to their organizations as they used to be some decades ago. They change employers more often and face difficulty seeking value in work relationships that often do not include socioemotional factors such as loyalty and job security. Given the lack of reciprocal loyalty, employees need to examine why they work so hard for their employer at the expense of their family, hobbies, and even their health [10]. Can CSR be a kind of "ideology" that justifies the employee's emotional bond with the organization? How do committed and uncommitted employees react to CSR practices? How does being committed or uncommitted moderate CSR outcomes? To answer these questions, hypotheses will be proposed in light of the above literature review. Based on the hypotheses, a theoretical model will then be developed and empirically verified. Finally, the results will be presented and discussed, and a conclusion will close the investigation.

Hypotheses

Reputation is a key CSRp outcome. CSRp gives companies a positive reputation among various stakeholder groups [53-55] and is associated with positive financial performance [56]. According to Neville et al. [57], reputation plays a major role in social and financial relationships. Story and Neves [36] found that organizations may jeopardize their position if they do not engage in CSRp, and it may harm their short-term and long-term performance. Thus, the following hypothesis has been developed:

H1. CSRp directly and positively influences companies' brand reputations.

Reputation improves brand value [58]. Porter and Kramer [59] and Lee [60] argued that short-term profits are no longer a company's primary aim. Thus, CSR-oriented companies use a profit-seeking approach in the long term, mainly by building up brand value [60]. López-Pérez et al. [61] stressed that CSRp enhances the brand image of a company and improves its financial value. Lai et al. [62] found that corporate reputation positively influences brand performance. Thus, the following hypothesis has been formulated:

H2. The stronger the company's brand reputation, the stronger the performance of the company's brand.

Expected Mediation

Mediation is observed when a third intervening variable supports the causal effect between the other two variables [63]. Based on the literature discussed above, brand reputation influences brand performance. Moreover, Torres et al. [64] found that CSR towards stakeholders (e.g., customers, shareholders, employees, suppliers, and communities) has a positive effect on global brand equity. Pratihari and Uzma [65], and Cowan and Guzman [66] identified a positive relationship between CSR, corporate branding, and brand loyalty, while Kowalczyk and Kucharska [24] found that CSRp indirectly influences corporate brand performance. Thus, brand reputation is expected to have a mediating effect on the relationship between CSRp and brand reputation. As a result, the following hypothesis has been formulated:

H3. CSRp indirectly and positively influences companies' brand performance.

Expected Moderated Mediation

Moderation explains the conditions under which a particular causal effect occurs [63]. It provides a better understanding of how a particular relationship is shaped by the existing condition. The condition may facilitate, enhance, or inhibit the effect [63]. In contrast to the intermediary variable (mediator), which explains "how" the causal effect occurs, the moderating variable (moderator) explains the conditions that change the effect of the causal effect. According to Karazsia and Berlin [67], the same variable can be considered both a mediator and a moderator, depending on the study's context and aims.

In the current study, it is expected that the mediated reputation effect of CSRp on brand performance will be moderated by employee brand commitment. In turn, this will lead to organizational citizenship 
behavior, which is perceived to be the best way to create superior value. The organizational citizenship behavior of employees results in their strong brand commitment, which is positively related to the expected benefits of CSR [16]. Cheung et al. [25] and Garas et al. [26] proved that internal branding dedicated to increasing employee commitment leads to significant brand performance improvement. Namely, in light of the literature review, we expect a moderated effect of employee brand commitment on the relationship between CSRp and corporate reputation. It is possible that a committed employee moderates all the above relationships. The dichotomous employee brand commitment representation of variable has been used intentionally to show clearly how the relationship between CSRp and brand reputation is shaped in conditions of high (1) and low (0) employee commitment. Hence, based on the explanation above, the following hypothesis has been formulated:

H4a. Employee brand commitment moderates the relationship between CSRp and brand performance.

Corporate brand reputation is the consequence of CSRp linked to employees [68]. Verčič and Ćorić [69] noted that strong employer brands have higher perceived reputations. This observation suggests that CSRp results in the greater commitment of employees to their company's brand. Hence, we should expect that the effect of CSRp on corporate reputation will be stronger for committed employees than for uncommitted employees. This expectation is reflected in the following hypothesis:

H4b. Employee brand commitment moderates the relationship between CSRp and brand reputation.

Expected Moderated Moderation

The hypothesized moderated mediation will be analyzed based on an international sample. Halkos and Skouloudis [70] noted that national CSR and institutional conditions are related; hence, CSRp may differ in various national societies. Therefore, a "country" moderator has been added to verify whether the employee brand commitment moderated effect on the relationship between CSRp and BP varies in different European countries, as suggested by Kowalczyk and Kucharska [24]. Hence, based on the above explanation, the hypothesis has been formulated as follows:

H5. The country factor moderates the relationship between CSRp and brand reputation moderated by employee brand commitment.

The structure of all hypothesized relationships is presented in Figure 1.

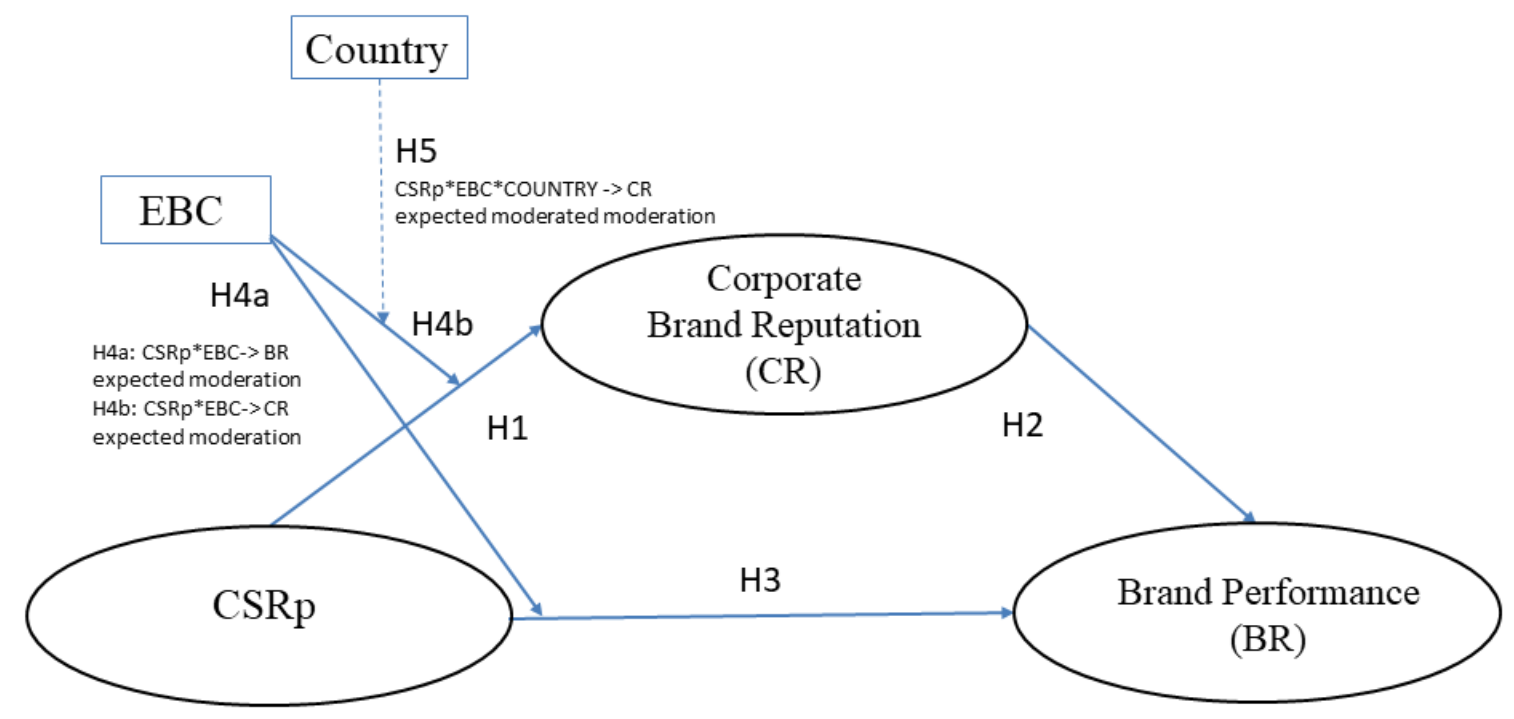

Figure 1. Theoretical model. 


\section{Method}

\subsection{Sample and Data Collection}

To achieve the aim of this study - that is, to assess the moderated effect of employee commitment on the relationship between CSRp and brand performance mediated by reputation-only employees who were familiar with brand results were invited to participate in the survey. Data were obtained electronically using a self-report questionnaire, mainly via emails addressed to HR departments of construction companies. To determine whether the respondents had the necessary knowledge to complete the questionnaire correctly, they had to have been working in the construction industry for more than one year and be familiar with the company's results at a general level during that period.

Before undertaking the main survey, a pilot study was run to improve the flow and understanding of the statements. Data were collected between April and June 2019. In total, 282 valid cases were gathered across Europe, including France (20\%), Great Britain (21\%), the Netherlands (19\%), Germany $(20 \%)$, and Poland (20\%). The sample was controlled to gather an equal number of cases from each country. The convenience method of sampling was employed in this research. HR departments of construction companies were asked for help in data gathering. Respondents had to work in the construction industry for more than one year and be members of a completed and assessed project. The country of origin of the organizations was controlled, but not the respondents' origin. Hence, the countries were selected by availability. Respondents answered voluntarily. Other countries, where the number of gained cases was lower than fifty, were excluded from the analysis. The construction industry is dominated by men, so it does not surprise that the majority of respondents were men $(96 \%)$ aged $26-35(43 \%)$ or $36-45(32 \%)$ who worked as team members $(78 \%)$ in large-sized $(39 \%)$ or medium-sized (28\%) companies. The Kaiser-Meyer-Olkin [71] test of the sample's adequacy to the measured factors was applied, and the obtained result was 0.929 , which is considered excellent. The total variance explained by the sample was $64 \%$, which was also positive $[72,73]$.

\subsection{Measures}

The eligible respondents answered questions adapted from validated measurement scales for all constructs included in the theoretical model. Appendix A, Table A1 lists the sources of the scales and statements, as well as reliabilities for each of the investigated constructs.

The subjects responded to statements based on a 7-point Likert scale using self-report questionnaires. To ensure that any potential bias in the responses was caused by the data gathering instrument (questionnaire) rather than the predisposition of the participants, Harman's single-factor test [74] was applied. The obtained result was $48 \%$; at less than $50 \%$, it was considered an acceptable level of bias [75]. So, the little bias detected was probably caused by gender factors or by the fact that big groups of respondents may come from the same companies (it was not controlled to ensure anonymity). Next, a common method variance test [76] of the "marker variable" was run, with an obtained result of $15 \%$. Thus, the potential bias level was low, and further analysis could proceed. Next, the Fornell-Larcker [77] criterion was used to verify potential cross-loading of the constructs by comparing the square root of each average variance extracted (AVE) in the diagonal with the correlation coefficients (off-diagonal) for each construct in the relevant rows and columns (see Table 2).

Table 2. Descriptive statistics and constructs correlation matrix with square root of the AVE on the diagonal.

\begin{tabular}{cccccccccc}
\hline & Mean & SD & AVE & CR & Cronbach alpha & CSRp & CR & BP & EBC \\
\hline CSRp & 5.39 & 1.030 & 0.61 & 0.86 & 0.86 & 0.783 & & & \\
\hline CR & 5.38 & 1.025 & 0.59 & 0.85 & 0.85 & 0.754 & 0.768 & & \\
\hline BP & 5.33 & 1.026 & 0.60 & 0.82 & 0.82 & 0.601 & 0.674 & 0.774 & \\
\hline EBC & $n a$ & $n a$ & $n a$ & $n a$ & $n a$ & 0.579 & 0.631 & 0.539 & $n a$ \\
\hline
\end{tabular}


AVE exceeded the minimum of 0.5 for all constructs, suggesting that the principal constructs captured much higher construct-related variance than error variance [72,73]. Cronbach's $\alpha$ was used to confirm the consistency of the measurement model. The Alpha coefficient was higher than 0.82 for all constructs, which was good [78]. The composite reliability was higher than 0.72 for all loadings, which was more than the required minimum of 0.7 [72,73], indicating internal consistency. Thus, all samples were good enough to create the empirical models and continue the study.

\subsection{Data Analysis Procedure}

The structural model estimation was preceded by employing the structural equation modeling method using SPSS AMOS 25 software. The model fit was assessed using the root mean square error of approximation (RMSEA) [79], the reference value of $\leq 0.08, \mathrm{CMIN} / \mathrm{df}$ [80], using a reference value of $\leq 5$, the Tacker-Lewis index (TLI) [81], and the comparative fit index (CFI) [82], using a reference value close to 1 for both. Hence, the data analysis proceeded as follows: first, a confirmatory factor analysis (CFA) measurement model was used to conduct factor analysis. Next, after the positive CFA evaluation, the structural model was developed and evaluated, including analysis of causal and mediated effects. Finally, PROCESS macro software [63] was employed to verify the hypothesized moderations.

\section{Results}

This study aimed to provide up-to-date knowledge about the structure and influence of employee commitment, corporate brand reputation, and brand performance in the construction industry in Europe. Based on the obtained results, all hypotheses formulated above were confirmed, except for $\mathrm{H} 4 \mathrm{a}$-regarding the moderated effect of employee brand commitment on CSRp and BP-which was not significant. H5 was partially confirmed. That is, the moderated effect of "country" is confirmed (statistically significant) only for Germany. This effect was not significant for Poland, France, Great Britain, and the Netherlands. Figures $2-5$ and Table 3 present the results of the study.

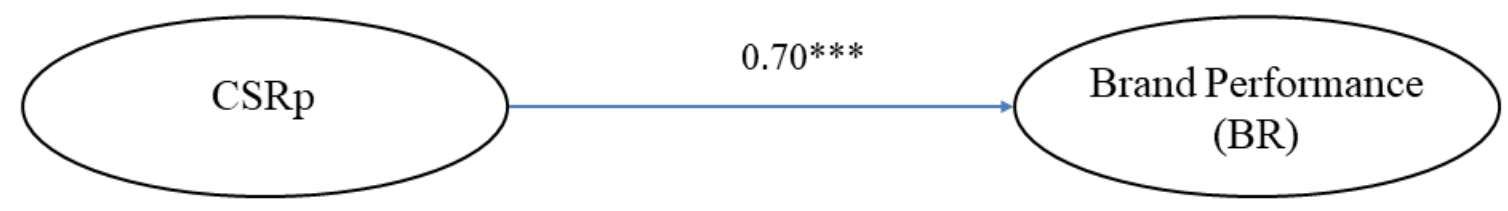

Figure 2. Structural model. Direct influence of CSRp on brand performance. Note: $n=282 \times 2(13)=31$ $\mathrm{CMIN} / \mathrm{df}=2.38 \mathrm{ML}$, standardized results, $\mathrm{RMSEA}=0.07,90 \% \mathrm{CI}[0.039,0.102], \mathrm{CFI}=0.981$, and $\mathrm{TLI}=$ 0.969. ${ }^{* * *} p<0.001$

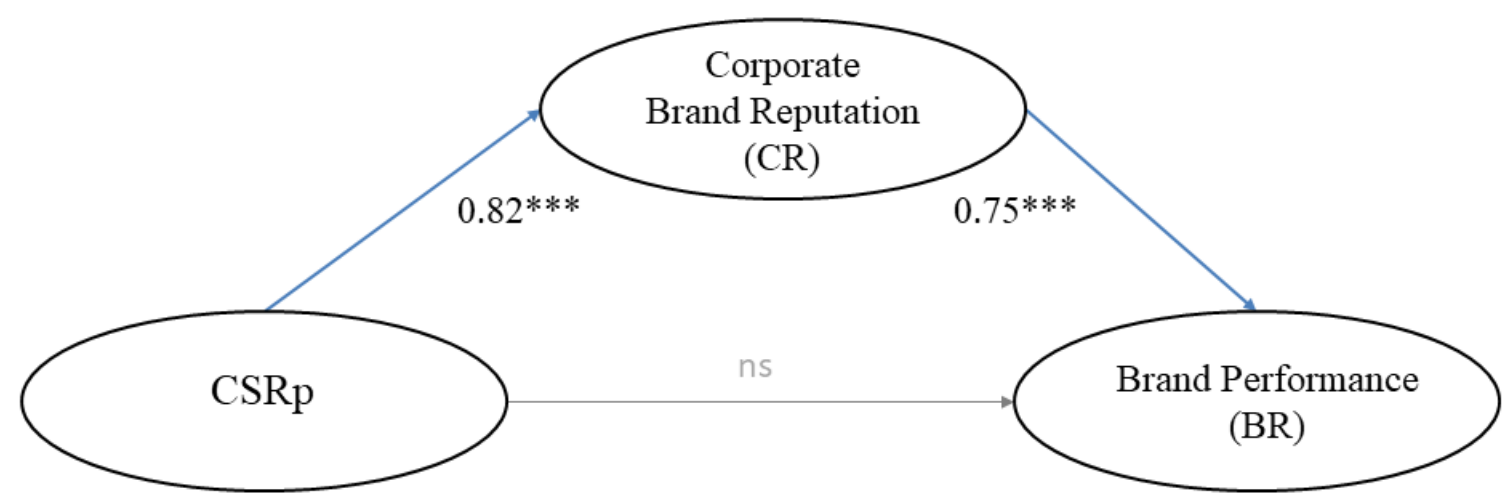

Figure 3. Structural model. Indirect (mediated) influence of CSRp on brand performance. Note: $\mathrm{n}=$ $282 \times 2(41)=85 \mathrm{CMIN} / \mathrm{df}=2.08 \mathrm{ML}$, standardized results, RMSEA $=0.062,90 \% \mathrm{CI}[0.043,0.081], \mathrm{CFI}=$ 0.974, and TLI $=0.965 .{ }^{*} p<0.05 .{ }^{* *} p<0.01 .{ }^{* * *} p<0.001$. 


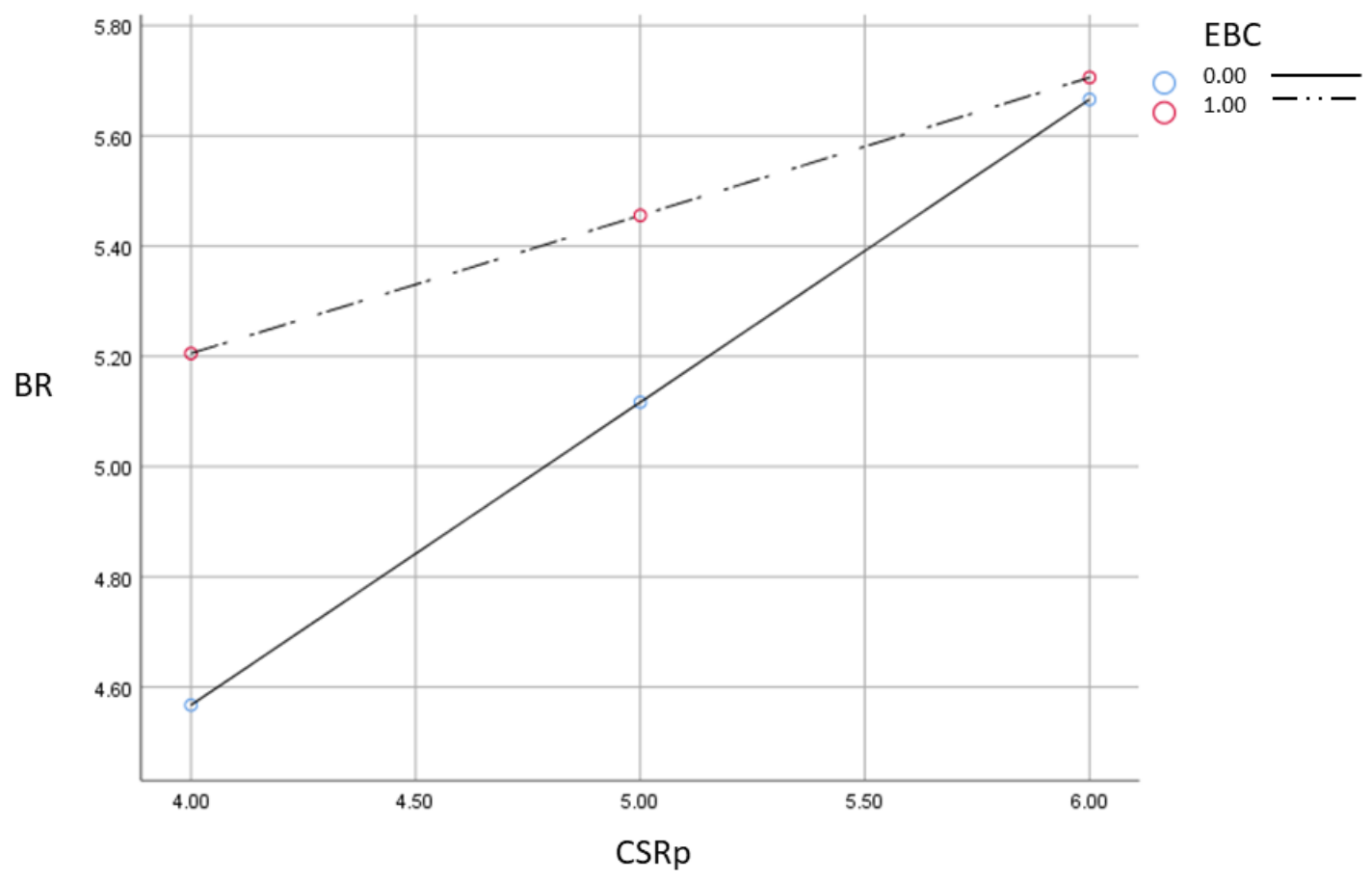

Figure 4. Regression model. Visualization of the focal predictor CSRp moderated by employee brand commitment effects on corporate reputation. Note: Moderator (employee brand commitment) is presented by dichotomous values: $0=$ low commitment, $1=$ strong commitment. PROCESS Model 8 has been applied. Standardized coefficients are not available for models with moderators.

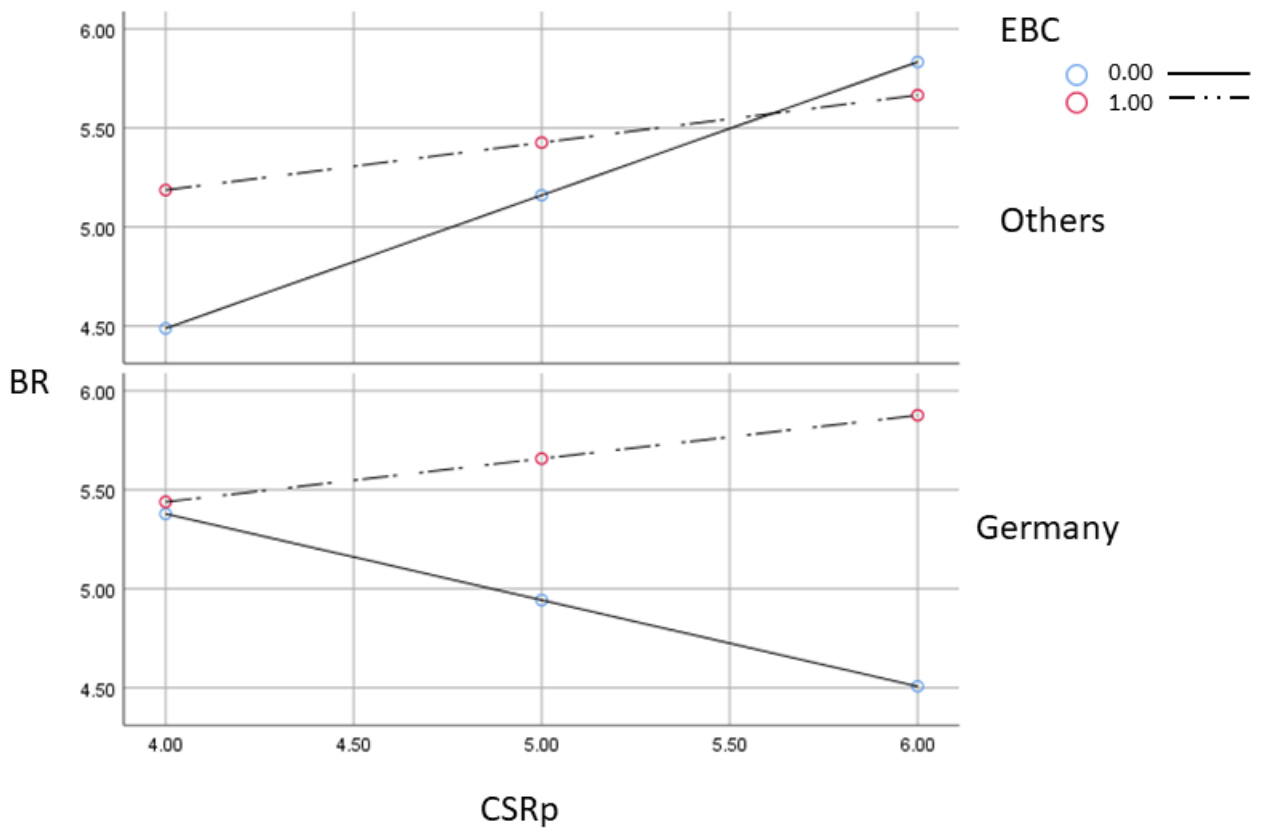

Figure 5. Regression model. Visualization of the focal predictor CSRp moderated by employee brand commitment moderated by "country" effects on corporate reputation. Note: Moderator (employee brand commitment) is presented by dichotomous values: $0=$ low commitment, $1=$ strong commitment. PROCESS Model 11 has been applied. Standardized coefficients are not available for models with moderators.

As Figure 4 shows, the effect of CSRp on corporate reputation in the total sample of highly committed employees is higher than in the group of not committed employees. Hence, a higher brand 
reputation effect is observed for high employee brand commitment. However, when CSRp is at the highest level, this "shift" effect is minimal. Thus, a high level of CSRp is very important if we want to build a corporate reputation. In the case of a lower level of CSRp, employee brand commitment supports reputation meaningfully. It means that the high level of CSRp is very efficient for corporate reputation, but only in cases where low employee brand commitment shifts it. Based on the verification of $\mathrm{H} 3$ and $\mathrm{H} 4$ presented in Table 3, the mediated effect of reputation for CSRp and BP relationship has been confirmed. Moreover, this mediation is stronger for less brand-committed employees. For those who are not committed, brand reputation driven by CSRp strongly supports perceived brand performance. For highly committed employees, the observed mediation effect is weaker. It means that employee brand commitment is a significant power that drives brand performance via reputation. It is reflected in the negative verification of H4a. The lack of the significant moderated effect of EBC on CSRp-BP relation is caused by the full mediated effect of corporate reputation on brand performance driven by CSRp. So, the employee brand commitment influence on brand performance by influencing on CSRp and brand reputation relation. Namely, it moderates this relation significantly (H4b).

Table 3. Results.

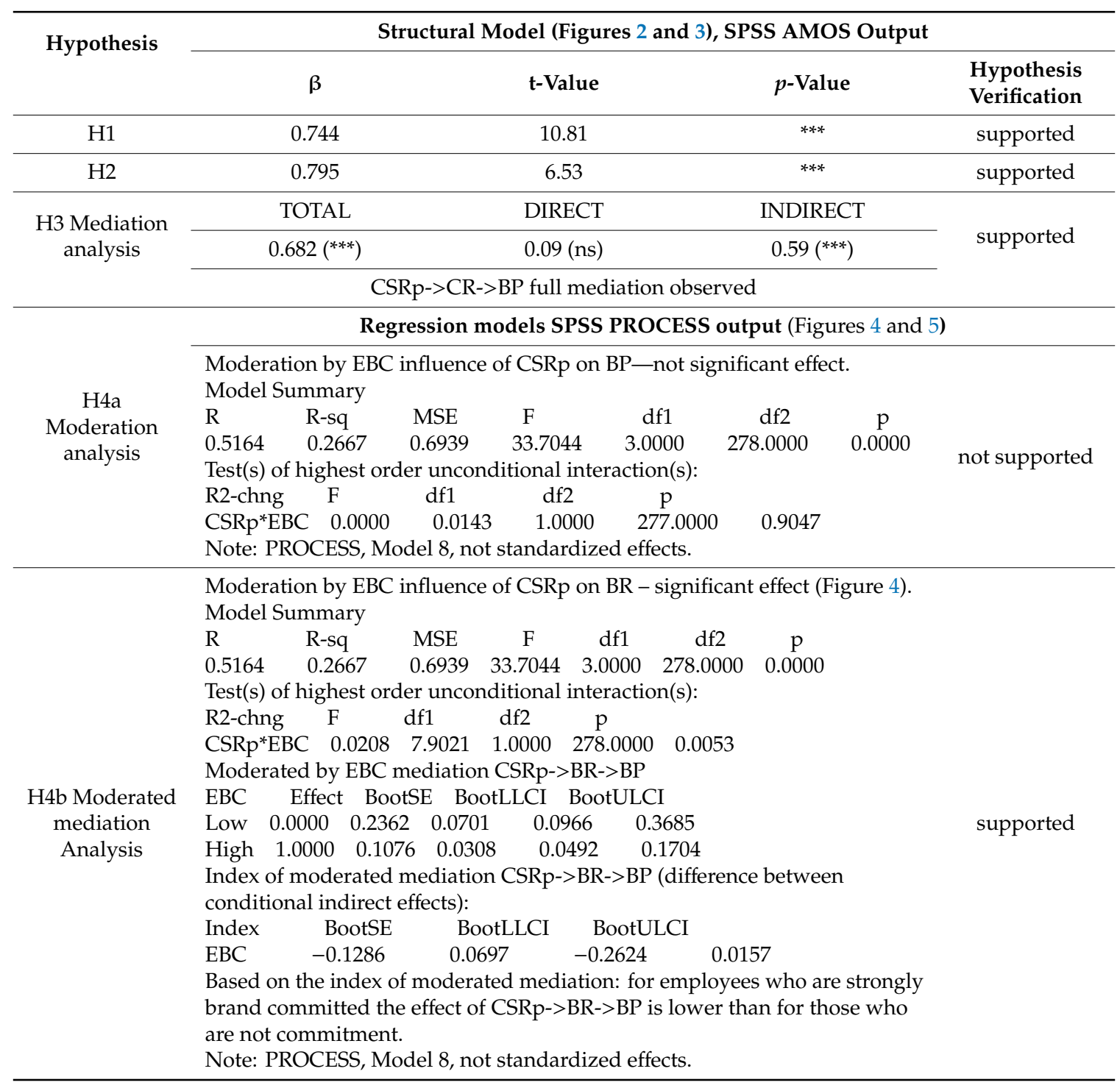


Table 3. Cont.

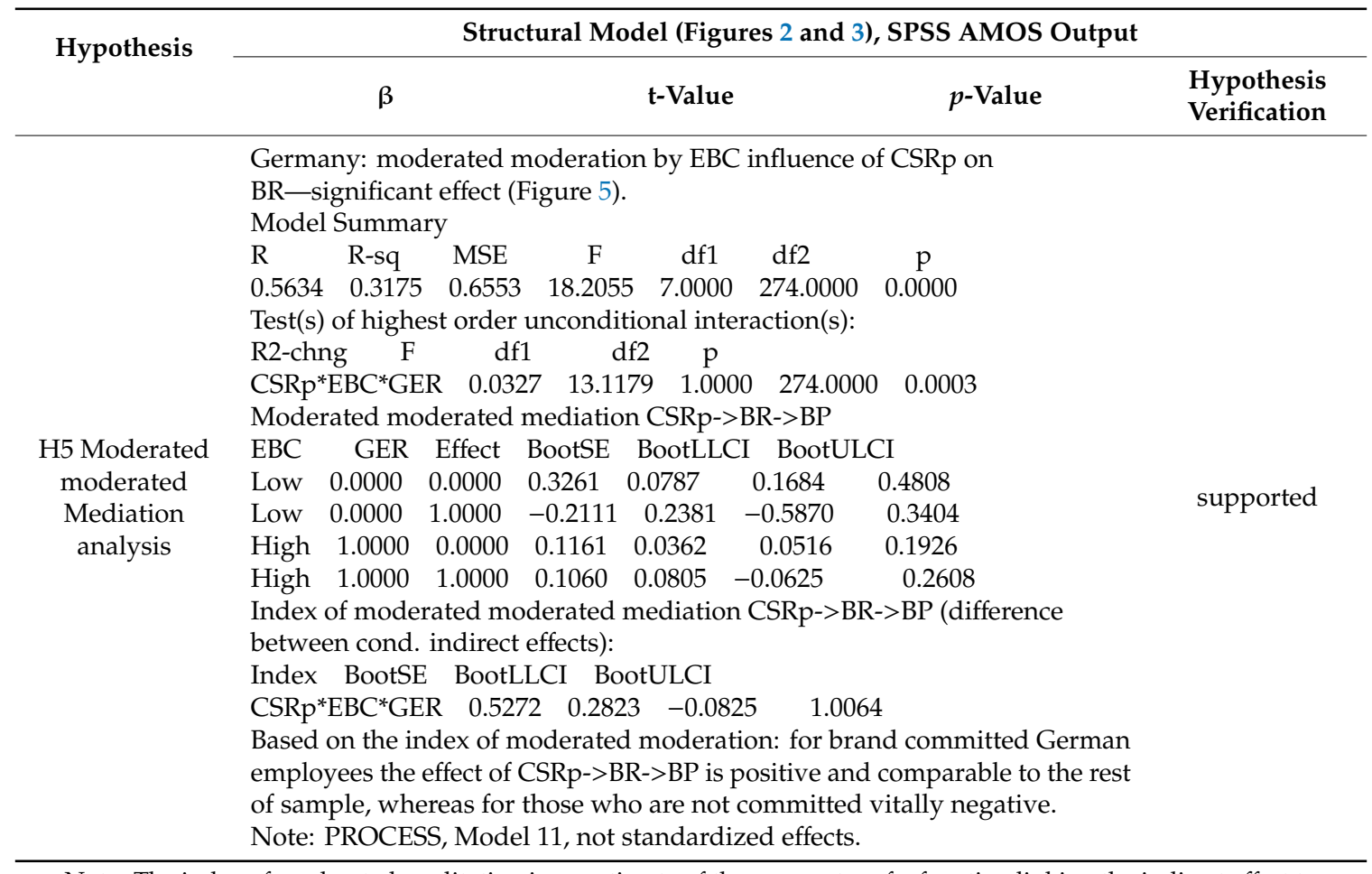

Note: The index of moderated meditation is an estimate of the parameter of a function linking the indirect effect to the values of a moderator (Hayes, 2018). The parameter is calculated on bootstrap samples. The test for moderated mediation is significant if the confidence interval excludes 0 . Level of confidence for all confidence intervals in the output: 95.0000 . Number of bootstrap samples for percentile bootstrap confidence intervals: 5000. Standardized coefficients are not available for models with moderators.

Thus, a high level of CSRp is important for final brand performance supported by brand reputation, especially for employees with low brand commitment. Results show that the high level of CSR may leverage corporate brand reputation even though employees are not brand committed. It shows how meaningful it is to secure an excellent level of CSR practice.

A surprising result was obtained for brand-committed German employees (see Figure 5; Table 3, $\mathrm{H} 5$ analysis). The effect of CSRp on corporate reputation was positive and comparable to the effect obtained for the total sample. Whereas for those of German employees who were not committed, the observed effect was negative. Therefore, we could conclude that corporate brand commitment is a much more powerful driver in Germany than in other countries, as shown by the strong negative results observed in the countries that lacked corporate brand commitment. Figure 5 shows that corporate reputation was higher in Germany than in Europe for both groups, i.e., committed and uncommitted, and that a high level of CSRp among uncommitted employees does not drive reputation, as observed for the rest of the sample. We could ask the question "why"? The discussion section proposes a hypothesized scenario.

\section{Discussion}

The most surprising result of the study was a negative moderated effect of focal mediation in the condition of a lack of brand commitment observed for Germany. The high level of corporate reputation for both: committed and uncommitted employees obtained at the same, middle level of CSRp suggests that German companies' reputations are generally highly perceived by both groups committed and uncommitted. However, for the uncommitted, the higher CSRp level is noted, the lower brand reputation is observed. It means that for this group, CSRp regulations have resulted in a negative effect. Therefore, the uncommitted may have a problem in adapting to and engaging with these regulations. Based on the sample of 1674 cases, Kowalczyk and Kucharska [24] noted the phenomenon 
of national CSR system consistency in Germany. It suggests that perhaps this uncommitted group does not originally come from Germany. The questionnaire only controlled the respondents' employer, for whom they worked for a year on a project that had been completed and assessed. However, the sample did not control the respondents' country of origin. The number of emigrants in Germany is quite high. Germany's foreign population reached a record of 10.6 million in 2017 [83]. According to the Central Register of Foreign Nationals, in 2018, there were approximately only 4.79 million nationals from the EU (from European culture) [84]. So, it may be that they have a problem with engaging with these regulations due to cultural issues. Hence, there is a chance that the hypothesized scenario explains the unexpected negative effect of CSRp on corporate reputation outcomes observed for uncommitted employees. However, this is just a hypothesis that requires to be verified. Another explanation is much simpler but tied with the previous one. It is a common habit that uncommitted persons feel even more alone and disappointed when the commitment of the majority rises. It makes them (uncommitted) feel even more alone.

Moreover, the indirect effect of CSRp via brand reputation moderated by employee commitment was larger and negative among uncommitted German employees. For the total sample, the moderated mediated effect was larger and positive for uncommitted employees. This shows that employee brand commitment is a kind of "superpower" in Germany. In the case of a lack of commitment, the observed brand reputation level decreased, even if the CSRp level rose. This also suggests that the involvement of a corporate brand in Germany is more important than in any other country, which is why the lack of a corporate brand is so severe and visible. Based on the Gallup German Engagement Index, Nink [85] highlighted that employee engagement is an essential factor linked to the economic value in Germany, and that German employees are brand ambassadors. Moreover, according to Effectory International [86], of the engagement and commitment indexes of all countries included in this study, the highest index was observed for Germany. Furthermore, as Kowalczyk and Kucharska [24] noted, Germany is characterized by a strong and consistent CSR business system in the construction industry. Hence, the lack of brand commitment negatively influenced the reputation output, even though the CSR level was high. It confirms that the law system creates the perception, and it is a consistent view in Germany. It may be a problem for somebody who does not share the same values as Germans do (e.g., culture or law). To conclude, this study confirms Ghosh's [87] findings and Wæraas and Dahle's [19] summary that the efficient reputation management of a company involves active people management in the company.

\section{Practical Implications}

This study shows that employee brand commitment is simply necessary and must be enhanced and supported by companies, even if people today do not work in one company for their entire career. Employee commitment strongly supports CSR outcomes, and the lack of it is a waste of human capital and is against the idea of a circular "zero waste" economy. Employee brand commitment is a strong influencing power. As Dixon-Fowler et al. [10] noted, the lack of reciprocal loyalty between temporary employees and their employers negatively impacts both groups. From a practical point of view, employee brand commitment is valuable and worth the investment. It is beneficial for companies because of its effects on company performance, and it is rewarding for employees and society because of how it affects the psychological wellbeing of people.

The study exposes the strong alignment of CSR and corporate brand reputation with strong brand commitment. Still, it also shows that the high level of CSR may leverage corporate brand reputation even though employees who are not brand committed. It shows how meaningful is the excellent level of CSR practice for an organization. Moreover, the study also reveals that the lack of employee brand commitment may jeopardize reputation. So, the CSR, brand reputation, and employee brand commitment are strongly related. Thus, the simplest way to achieve sustainability is to keep employee brand commitment and CSR on the possible highest levels to secure corporate brand reputation and brand performance effects. 


\section{Limitation and Further Research}

The main limitation of the current study was its comparably small sample. Each of the five countries was represented by around 50 cases. It would be interesting to replicate the study using a larger sample, which would enable the creation of full structural models for each country. Moreover, the little bias detected was probably caused by gender factors, or by the fact that large groups of respondents may have come from the same companies (it was not controlled to ensure anonymity).

According to Effectory International [86], the highest engagement and commitment index in Europe is observed for Austria. Hence, it would be interesting to determine how employee brand commitment moderates CSRp -> brand reputation -> BP mediation in Austria (35.4\%). A comparison between Austria and Germany could have important implications based on studies conducted in Germany [24,85]. Further, other CSR outcomes linked to employee brand commitment could provide a broader understanding of the complexity of the phenomenon. Moreover, the study which controls not only the respondent's place of work, but also the country of origin may bring interesting practical implications and verify the hypothesis given in the discussion section.

\section{Conclusions}

This study aimed to provide up-to-date knowledge on the structure and influence of employee commitment, corporate brand reputation, and brand performance in the construction industry in Europe. The findings suggest that employee brand commitment is, in a way, a "superpower" that shapes CSRp outcomes. This conclusion suggests that the future of corporate brands is in employees' hands. Thus, employee brand commitment is a valuable and worthwhile investment. Therefore, the companies should do all they can to turn uncommitted employees into committed ones. This study focuses on the attention the companies should pay to enhance employee commitment today to achieve better brand performance in the future. Moreover, the presented evidence suggests the importance of internal branding as a tool supporting commitment.

Funding: This research received no external funding.

Conflicts of Interest: The authors declare no conflict of interest.

Appendix A Scales, Sources, and Reliabilities

Table A1. Scales, sources, and reliabilities

\begin{tabular}{|c|c|c|}
\hline Construct & Scale & Reliability assessment \\
\hline $\begin{array}{l}\text { CSR practice, adapted } \\
\text { from You and Choi [88]; } \\
\text { Eisingerich and } \\
\text { Rubera [45]; } \\
\text { He and Li, [50] }\end{array}$ & $\begin{array}{l}\text { The organization is socially responsible. } \\
\text { My company cares about the local community. } \\
\text { It is important to act ethically. } \\
\text { The company cares about the environment. }\end{array}$ & $\begin{array}{c}\mathrm{AVE}=0.61 \\
\mathrm{CR}=0.86 \\
\text { Cronbach's } \alpha=0.863\end{array}$ \\
\hline $\begin{array}{l}\text { Corporate reputation } \\
(\mathrm{CR})) \text {, adapted from } \\
\text { Lai et al. [62] }\end{array}$ & $\begin{array}{l}\text { Our customers' overall perception of total } \\
\text { experience in the firm is rather good. } \\
\text { Our customers perceive us better than others. } \\
\text { Our customers claim that we are doing well. } \\
\text { Our customers are positive about our future. }\end{array}$ & $\begin{array}{c}\mathrm{AVE}=0.59 \\
\mathrm{CR}=0.85 \\
\text { Cronbach's } \alpha=0.85\end{array}$ \\
\hline $\begin{array}{l}\text { Brand performance }(\mathrm{BP}), \\
\text { adapted from } \\
\text { Lai et al. [62] }\end{array}$ & $\begin{array}{l}\text { Customers choosing us are increasing our } \\
\text { sales growth. } \\
\text { Customers choosing us enlarge our market share. } \\
\text { Customers choosing us improve our margin. } \\
\text { Customers choosing us improve our brand's } \\
\text { overall performance. }\end{array}$ & $\begin{array}{c}\mathrm{AVE}=0.60 \\
\mathrm{CR}=0.82 \\
\text { Cronbach's } \alpha=0.82\end{array}$ \\
\hline $\begin{array}{l}\text { Employee brand } \\
\text { commitment }\end{array}$ & I am proud of our brand (Yes/No). & na \\
\hline
\end{tabular}




\section{References}

1. Barwise, P.; Higson, C.; Likierman, A.; Marsh, P. Brands as separable assets. Bus. Strategy Rev. 1990, 1, 43-59. [CrossRef]

2. Kucharska, W.; Flisikowski, K.; Confente, I. Do global brands contribute to the economy of their country of origin? A dynamic spatial approach. J. Prod. Brand Manag. 2018, 27, 768-780. [CrossRef]

3. Aon Hewitt. 2017 Trends in Global Employee Engagement. 2017. Available online: http://images.respond.aonhewitt.com/Web/AonHewitt/\%7Bd9a8975c-f5b1-4105-8dfd-63a835f3213b\%7D_ 2017-Trends-in-Global-Employee-Engagement.pdf (accessed on 15 December 2019).

4. Ellen MacArthur Foundation. Towards the Circular Economy: An Economic and Business Rationale for an Accelerated Transition. 2012. Available online: https:/www.ellenmacarthurfoundation.org/assets/ downloads/publications/Ellen-MacArthur-Foundation-Towards-the-Circular-Economy-vol.1.pdf (accessed on 15 December 2019).

5. Clarkson, M.E. A stakeholder framework for analyzing and evaluating corporate social performance. Acad. Manag. Rev. 1995, 20, 92-117. [CrossRef]

6. Venturelli, A.; Cosma, S.; Leopizzi, R. Stakeholder engagement: An evaluation of European banks. Corp. Soc. Responsib. Environ. Manag. 2018, 25, 690-703. [CrossRef]

7. Testa, F.; Boiral, O.; Heras-Saizarbitoria, I. Improving CSR performance by hard and soft means: The role of organizational citizenship behaviours and the internalization of CSR standards. Corp. Soc. Responsib. Environ. Manag. 2018, 25, 853-865. [CrossRef]

8. Hamadamin, H.H.; Atan, T. The Impact of Strategic Human Resource Management Practices on Competitive Advantage Sustainability: The Mediation of Human Capital Development and Employee Commitment. Sustainability 2019, 11, 5782. [CrossRef]

9. Bringham, J.B.; Mitchell, B.W.; Bishop, D.G.; Allen, N.J. Working for a higher purpose: A theoretical framework for commitment to organization-sponsored causes. Hum. Resour. Manag. Rev. 2013, 23, 174-189. [CrossRef]

10. Johnson, R.E.; Chang, C.-H.; Yang, L.-Q. Commitment and motivation at work: The relevance of employee identity and regulatory focus. Acad. Manag. Rev. 2010, 35, 226-245. [CrossRef]

11. Dixon-Fowler, H.; O'Leary-Kelly, A.; Johnson, J.; Waite, M. Sustainability and ideology-infused psychological contracts: An organizational- and employee-level perspective. Hum. Resour. Manag. Rev. 2019. [CrossRef]

12. Meyer, J.P.; Herscovitch, L. Commitment in the workplace: Toward a general model. Hum. Resour. Manag. Rev. 2001, 11, 299-326. [CrossRef]

13. Becker, H.S. Notes on the concept of commitment. Am. J. Sociol. 1960, 66, 32-40. [CrossRef]

14. Becker, T.E.; Billings, R.S.; Eveleth, D.M.; Gilbert, N.L. Foci and bases of employee commitment: Implications for job performance. Acad. Manag. J. 1996, 39, 464-482. [CrossRef]

15. Ravens, C. Internal brand management in an international context. In Innovatives Markenmanagement; Springer Gabler: Wiesbaden, Germany, 2014; Volume 47, pp. 3-10.

16. Piehler, R. Employees' brand understanding, brand commitment, and brand citizenship behaviour: A closer look at the relationships among construct dimensions. J. Brand Manag. 2018, 25, 217-234. [CrossRef]

17. da Graça Marques Casimiro Almeida, M.; Fernandes Matos Coelho, A. The antecedents of corporate reputation and image and their impacts on employee commitment and performance: The moderating role of CSR. Corp. Reput. Rev. 2018, 22. [CrossRef]

18. Hoppe, D. Linking employer branding and internal branding: Establishing perceived employer brand image as an antecedent of favourable employee brand attitudes and behaviours. J. Prod. Brand Manag. 2018, 27, 452-467. [CrossRef]

19. Wæraas, A.; Dahle, D.Y. When reputation management is people management: Implications for employee voice. Eur. Manag. J. 2020. [CrossRef]

20. de Chernatony, L.; Drury, S.; Segal-Horn, S. Communicating services brands' values internally and externally. Serv. Ind. J. 2006, 26, 819-836. [CrossRef]

21. Brodie, R.J.; Glynn, M.S.; Little, V. The service brand and the service-dominant logic: Missing fundamental premise or the need for stronger theory? Mark. Theory 2006, 6, 363-379. [CrossRef]

22. Gupta, M. Corporate social responsibility, employee-company identification, and organizational commitment: Mediation by employee engagement. Curr. Psychol. 2017, 36, 101-109. [CrossRef] 
23. Kucharska, W.; Kowalczyk, R. How to achieve sustainability? Employee's point of view on company's culture and CSR practice. Corp. Soc. Responsib. Environ. Manag. 2019, 26, 453-467. [CrossRef]

24. Kowalczyk, R.; Kucharska, W. Corporate social responsibility practices incomes and outcomes: Stakeholders' pressure, culture, employee commitment, corporate reputation, and brand performance. A Polish-German cross-country study. Corp. Soc. Responsib. Environ. Manag. 2019. [CrossRef]

25. Cheung, C.; Kong, H.; Song, H. How to influence hospitality employee perceptions on hotel brand performance? Int. J. Contemp. Hosp. Manag. 2014, 26, 1162-1178. [CrossRef]

26. Garas, S.R.R.; Mahran, A.F.A.; Mohamed, H.M.H. Internal corporate branding impact on employees' brand supporting behaviour. J. Prod. Brand Manag. 2018, 27, 79-95. [CrossRef]

27. Lepak, D.; Smith, K.; Taylor, M.S. Value creation and value capture: A multilevel perspective. Acad. Manag. Rev. 2007, 32, 180-194. [CrossRef]

28. Kamakura, W.A.; Russell, G.J. Measuring brand value with scanner data. Int. J. Res. Mark. 1993, 10, 9-22. [CrossRef]

29. Piehler, R.; King, C.; Burmann, C.; Xiong, L. The importance of employee brand understanding, brand identification, and brand commitment in realizing brand citizenship behavior. Eur. J. Mark. 2016, 50, 1575-1601. [CrossRef]

30. Nygaard, A.; Biong, H. The influence of retail management's use of social power on corporate ethical values, employee commitment, and performance. J. Bus. Ethics 2010, 97, 87-108. [CrossRef]

31. Burmann, C.; Zeplin, S. Building brand commitment: A behavioural approach to internal brand management. J. Brand Manag. 2005, 12, 279-300. [CrossRef]

32. Opoku-Dakwa, A.; Chen, C.C.; Rupp, D.E. CSR initiative characteristics and employee engagement: An impact-based perspective. J. Organ. Behav. 2018, 39, 580-593. [CrossRef]

33. Pedersen, E.R.G. All animals are equal, but ... : Management perceptions of stakeholder relationships and societal responsibilities in multinational corporations. Bus. Ethics Eur. Rev. 2011, 20, 177-191. [CrossRef]

34. Rodrigo, P.; Aqueveque, C.; Duran, I.J. Do employees value strategic CSR? A tale of affective organizational commitment and its underlying mechanisms. Bus. Ethics 2019, 28, 459-475. [CrossRef]

35. Rosati, F.; Costa, R.; Calabrese, A.; Pedersen, E.R.G. Employee attitudes towards corporate social responsibility: A study on gender, age and educational level differences. Corp. Soc. Responsib. Environ. Manag. 2018, 25, 1306-1319. [CrossRef]

36. Story, J.; Neves, P. When corporate social responsibility (CSR) increases performance: Exploring the role of intrinsic and extrinsic CSR attribution. Bus. Ethics Eur. Rev. 2015, 24, 111-124. [CrossRef]

37. McShane, L.; Cunningham, P. To thine own self be true? Employees' judgments of the authenticity of their organization's corporate social responsibility program. J. Bus. Ethics 2012, 108, 81-100. [CrossRef]

38. Glavas, A. Corporate social responsibility and employee engagement: Enabling employees to employ more of their whole selves at work. Front. Psychol. 2016, 7, 796. [CrossRef]

39. Glavas, A.; Godwin, L.N. Is the perception of 'goodness' good enough? Exploring the relationship between perceived corporate social responsibility and employee organizational identification. J. Bus. Ethics 2013, 114, 15-27. [CrossRef]

40. Glavas, A.; Kelley, K. The effects of perceived corporate social responsibility on employee attitudes. Bus. Ethics Q. 2014, 24, 165e202. [CrossRef]

41. Caligiuri, P.; Mencin, A.; Jiang, K. Win-win-win: The influence of company-sponsored volunteerism programs on employees, NGOs, and business units. Pers. Psychol. 2013, 66, 825-860. [CrossRef]

42. Gond, J.P.; El Akremi, A.; Swaen, V.; Babu, N. The psychological microfoundations of corporate social responsibility: A person-centric systematic review. J. Organ. Behav. 2017, 38, 225-246. [CrossRef]

43. Dhanesh, G.S. CSR as organization-employee relationship management strategy: A case study of socially responsible information technology companies in India. Manag. Commun. Q. 2014, 28, 130-149. [CrossRef]

44. Eisingerich, A.B.; Rubera, G. Drivers of brand commitment: A cross-national investigation. J. Int. Mark. 2010, 18, 64-79. [CrossRef]

45. Farooq, O.; Payaud, M.; Merunka, D.; Valette-Florence, P. The impact of corporate social responsibility on organizational commitment: Exploring multiple mediation mechanisms. J. Bus. Ethics 2014, 125, 563-580. [CrossRef] 
46. Hofman, P.S.; Newman, A. The impact of perceived corporate social responsibility on organizational commitment and the moderating role of collectivism and masculinity: Evidence from China. Int. J. Hum. Resour. Manag. 2014, 25, 631-652. [CrossRef]

47. Carmeli, A.; Gilat, G.; Waldman, D.A. The role of perceived organizational performance in organizational identification, adjustment and job performance. J. Manag. Stud. 2007, 44, 972-992. [CrossRef]

48. He, H.; Li, Y. CSR and service brand: The mediating effect of brand identification and moderating effect of service quality. J. Bus. Ethics 2011, 100, 673-688. [CrossRef]

49. Kim, H.R.; Lee, M.; Lee, H.T.; Kim, N.M. Corporate social responsibility and employee-company identification. J. Bus. Ethics 2010, 95, 557-569. [CrossRef]

50. Thompson, J.A.; Bunderson, J.S. Violations of principle: Ideological currency in the psychological contract. Acad. Manag. Rev. 2003, 28, 571-586. [CrossRef]

51. Allen, N.J.; Meyer, J.P. The measurement and antecedents of affective, continuance and normative commitment to the organization. J. Occup. Psychol. 1990, 63, 1-18. [CrossRef]

52. McWilliams, A.; Siegel, D.S. Corporate social responsibility: A theory of the firm perspective. Acad. Manag. Rev. 2001, 26, 117-127. [CrossRef]

53. Melo, T.; Garrido-Morgado, A. Corporate reputation: A combination of social responsibility and industry. Corp. Soc. Responsib. Environ. Manag. 2012, 19, 11-31. [CrossRef]

54. Michelon, G. Sustainability disclosure and reputation: A comparative study. Corp. Reput. Rev. 2011, 14, 79-96. [CrossRef]

55. Sen, S.; Bhattacharya, C.B. Doing better at doing good: When, why and how consumers respond to corporate social initiatives. Calif. Manag. Rev. 2004, 47, 9-24. [CrossRef]

56. Michelon, G.; Boesso, G.; Kumar, K. Examining the link between strategic corporate social responsibility and company performance: An analysis of the best corporate citizens. Corp. Soc. Responsib. Environ. Manag. 2013, 20, 81-94. [CrossRef]

57. Neville, B.; Bell, S.; Mengüç, B. Corporate reputation, stakeholders and the social performance-financial performance relationship. Eur. J. Mark. 2005, 39, 1184-1198. [CrossRef]

58. Lee, K.H.; Herold, D.M.; Yu, A.L. Small and medium enterprises and corporate social responsibility practice: A Swedish perspective. Corp. Soc. Responsib. Environ. Manag. 2016, 23, 88-99. [CrossRef]

59. Porter, M.E.; Kramer, M.R. Creating shared value. Harv. Bus. Rev. 2011, 89, 62-77.

60. Lee, K.H. Linking stakeholders and corporate reputation towards corporate sustainability. Int. J. Innov. Sustain. Dev. 2012, 6, 219-235. [CrossRef]

61. López-Pérez, M.E.; Merelo-Polo, I.; Vázquez-Carrasco, R.; Cambra-Fierro, J. Sustainability and business outcomes in the context of SMEs: Comparing family firms vs. non-family firms. Sustainability 2018, 10, 4080. [CrossRef]

62. Lai, C.-S.; Chiu, C.-J.; Yang, C.-F.; Pai, D.-C. The effects of corporate social responsibility on brand performance: The mediating effect of industrial brand equity and corporate reputation. J. Bus. Ethics 2010, 95, 457-469. [CrossRef]

63. Hayes, A. Introduction to Mediation, Moderation and Conditional Process Analysis: A Regression-Based Approach, 2nd ed.; Guilford Press: New York, NY, USA, 2018.

64. Torres, A.; Bijmolt, T.H.A.; Tribo, J.A.; Verhoef, P. Generating global brand equity through corporate social responsibility to key stakeholders. Int. J. Res. Mark. 2012, 29, 13-24. [CrossRef]

65. Pratihari, S.K.; Uzma, S.H. CSR and corporate branding effect on brand loyalty: A study on Indian banking industry. J. Prod. Brand Manag. 2018, 27, 57-78. [CrossRef]

66. Cowan, K.; Guzman, F. How CSR reputation, sustainability signals, and country-of-origin sustainability reputation contribute to corporate brand performance: An exploratory study. J. Bus. Res. 2019. [CrossRef]

67. Karazsia, B.; Berlin, K.S. Can a mediator moderate? Considering the role of time and change in the mediator-moderator distinction. Behav. Ther. 2018, 49, 12-20. [CrossRef]

68. Hur, W.M.; Moon, T.W.; Lee, H.G. Employee engagement in CSR initiatives and customer-directed counterproductive work behavior (CWB): The mediating roles of organizational civility norms and job calling. Corp. Soc. Responsib. Environ. Manag. 2018, 25, 1087-1098. [CrossRef]

69. Verčič, A.T.; Ćorić, D.S. The relationship between reputation, employer branding and corporate social responsibility. Public Relat. Rev. 2018, 44, 444-452. [CrossRef] 
70. Halkos, G.; Skouloudis, A. National CSR and institutional conditions: An exploratory study. J. Clean. Prod. 2016, 139, 1150-1156. [CrossRef]

71. Kaiser, H. An index of factor simplicity. Psychometrika 1974, 39, 31-36. [CrossRef]

72. Hair, J.F.; Anderson, R.E.; Babin, B.J.; Black, W.C. Multivariate Data Analysis: A Global Perspective; Pearson: Upper Saddle River, NJ, USA, 2010.

73. Byrne, B.M. Structural Equation Modeling with Amos; Routledge: New York, NY, USA, 2016.

74. Podsakoff, P.M.; Organ, D. Self-reports in organizational research: Problems and prospects. J. Manag. 1986, 12, 531-544. [CrossRef]

75. Podsakoff, P.M.; MacKenzie, S.B.; Lee, J.-Y.; Podsakoff, N.P. Common method biases in behavioral research: Acritical review of the literature and recommended remedies. J. Appl. Psychol. 2003, 88, 879-903. [CrossRef]

76. Lindell, M.K.; Whitney, D.J. Accounting for common method variance in cross-sectional research designs. J. Appl. Psychol. 2001, 86, 114-121. [CrossRef]

77. Fornell, C.; Larcker, D.F. Evaluating structural equation models with unobservable variables and measurement error. J. Mark. Res. 1981, 18, 39-50. [CrossRef]

78. Francis, G. Introduction to SPSS for Windows, 3rd ed.; Pearson Education: Sydney, NSW, Australia, 2001.

79. Steiger, J.H.; Lind, J.C. Statistically Based Tests for the Number of Common Factors. In Proceedings of the Annual Meeting of the Psychometric Society, Iowa City, IA, USA, May 1980.

80. Wheaton, D.E.; Muthen, B.; Alwin, D.F.; Summers, G.F. Assessing reliability and stability in panel models. Sociol. Methodol. 1977, 8, 84-136. [CrossRef]

81. Bollen, K.A. Structural Equations with Latent Variables; John Wiley \& Sons: New York, NY, USA, 1989.

82. McDonald, R.P.; Marsh, H.W. Choosing a multivariate model: Noncentrality and goodness of fit. Psychol. Bull. 1990, 107, 247-255. [CrossRef]

83. Dw.com. Germany's Foreign Population Reaches Record 10.6 Million. 2017. Available online: https://www.dw.com/en/germanys-foreign-population-reaches-record-106-million/a-43353320 (accessed on 15 December 2019).

84. Statista.com. Number of foreigners in Germany in 2018, by Region of Origin. 2018. Available online: https://www.statista.com/statistics/891324/foreigner-numbers-by-region-of-origin-germany/ (accessed on 15 December 2019).

85. Nink, M. Engagement Index Deutschland. 2015. Available online: http://www.gallup.com/de-de/181871/ engagement-index-deutschland.aspx (accessed on 15 December 2019).

86. Effectory International. The Essential Guide to Driving Employee Engagement in Europe. 2019. Available online: http://www.efectory.com (accessed on 30 November 2019).

87. Ghosh, K. How and when do employees identify with their organization? Perceived CSR, first-party (in)justice, and organizational (mis)trust at workplace. Pers. Rev. 2018, 47, 1152-1171. [CrossRef]

88. Yu, Y.; Choi, Y. Stakeholder pressure and CSR adoption: The mediating role of organizational culture for Chinese companies. Soc. Sci. J. 2016, 53, 226-235. [CrossRef]

(C) 2020 by the author. Licensee MDPI, Basel, Switzerland. This article is an open access article distributed under the terms and conditions of the Creative Commons Attribution (CC BY) license (http://creativecommons.org/licenses/by/4.0/). 